Research Article

\title{
What influences the willingness of citizens to coproduce public services? Results from a vignette experiment
}

\section{Fabian Hattke*, Janne Kalucza*}

\begin{abstract}
A growing body of literature has investigated the involvement of private and third-sector organizations in the provision and maintenance of public goods. Still, there is little empirical knowledge about the reasons for individual citizens to coproduce public services. Research discusses several motivational and situational factors as important antecedents. We elaborate on this framework and test the effect of the relationships proposed by the literature in a survey experiment by modelling a realistic coproduction situation in the context of city waste management. Our results show that general motivations are not a predictor of the individual willingness to coproduce, while context-specific self-efficacy, intrinsic, and prosocial motivation are. Furthermore, access to coproduction resources and expected personal benefits positively influence the willingness to coproduce, while performance delay has a negative effect. A post-hoc analysis identifies two distinct types of coproducers: a decisive type, whose willingness is most strongly influenced by intrinsic motivation; and a flexible type whose coproduction intention only depends on situational factors. These detailed insights yield valuable implications for public administrations that want to engage citizens in the provision of public goods.
\end{abstract}

Keywords: Coproduction, Citizen-state interaction, Environmental behavior, Low-cost situation, Motivation

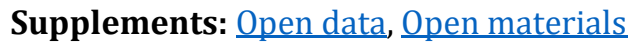

$\mathrm{M}$ any public services are no longer delivered only by professionals but require active citizen contributions. Among the most prominent drivers of this development are the downsizing of the public sector, technological innovations, and societal demands for a broader participation of stakeholders in local communities (e.g., Bovaird, Van Ryzin, Loeffler, \& Parrado, 2015; Osborne \& Strokosch, 2013; Voorberg, Jilke, Tummers, \& Bekkers, 2018). A substantial body of literature has been concerned with the pivotal role of voluntary and non-profit organizations in the so-called third sector (Brandsen \& Pestoff, 2006). However, an

\footnotetext{
* Department of Socioeconomics, Universität

Hamburg

Address correspondence to Fabian Hattke at

fabian.hattke@uni-hamburg.de

Copyright: (C) 2019. The authors license this article under the terms of the Creative Commons Attribution 4.0 International License.
}

immediate and less organized form of coproduction by individual citizens indicates a new trend. The direct involvement of members of the community in the delivery of public services has been researched in different contexts like recycling initiatives (Riccucci, Van Ryzin, \& Li, 2016), developing a city's marketing guidelines (Aschhoff \& Vogel, 2018), and the provision of language courses for refugees (Voorberg et al., 2018). A central question in this literature is what motivates individual citizens to coproduce and how coproduction initiatives should be designed so that active citizenship can be increased.

Some studies suggested situational factors and showed that having access to resources (Jakobsen, 2013) and expecting personal benefits (Thomsen \& Jakobsen, 2015) positively influence engagement in coproduction, whereas extrinsic rewards seem to have only marginal influence on the engagement of citizens (Voorberg et al., 2018). We expand on these findings and consider coproduction as a lowcost or multiple-exit situation (Latsis, 1972). These 
situations are characterized by the insignificant impact of an individual's decision, while there are no or little external factors that restrict the individual's choice (Mensch, 2000). In contrast, high-cost situations severely limit the discretionary powers of the individual by strong situational constraints (Mensch, 2000). While rational choice theory can explain human behavior well in high-cost situations, its explanatory power is rather limited when trying to describe behavior in low-cost situations in which the individual's preferences, traits, and motivations come into focus (Diekmann \& Preisendörfer, 2003).

Interestingly, the theoretical assumption underlying most research on coproduction, namely that the most important motivational antecedents are intrinsic, (pro-)social, and normative motivation (as for involvement in the third sector, see Alford, 2009), has only scarcely been assessed empirically so far (Andersen, Jakobsen. Seritzlew, \& Thomsen, 2017). This article aims to address this issue by investigating the influence of motivational antecedents, together with situational factors, on citizens' willingness to coproduce. We are interested to see how strongly citizens are influenced by which kind of motivational antecedent and how varying situational conditions might shift the individual's tendency towards considering coproducing.

Our aim is to investigate the willingness of citizens to coproduce environmental services. Parallel to research on coproduction, research on environmental behavior has explored similar concepts such as motivation, attitude, and skill in low-cost-situations (Diekmann \& Preisendörfer, 2003). Especially in the context of litter and recycling, it bears great similarities to the concept of coproduction (see Ahmad, Bazmi, Bhutto, Shahzadi, \& Bukhari, 2016; Wan, Shen, \& Yu, 2014). Building on insights from the literature on both coproduction and environmental behavior, this study examines an actual coproduction initiative to reduce littering set up by the City of Hamburg, Germany, to assess the willingness of citizens to coproduce. In a $3 \times 2$ vignette experiment, we empirically investigated how motivational antecedents influence citizen willingness to coproduce and how motivation interacts with situational factors. 208 citizens (students) were asked whether they would participate in the city's coproduction initiative, which consists of an app and a hotline for citizens to report garbage dumping to the local authorities.
The remainder of this article is structured as follows: We first introduce the main concepts and develop a theoretical framework on which we base our hypotheses. We then describe our research design and present results from our study. Finally, we discuss our findings and draw conclusions for future research and practice.

\section{Theoretical Framework}

\section{Coproduction}

Coproduction is defined as "a relationship between a paid employee of an organization and (groups of) individual citizens that requires a direct and active contribution from these citizens to the work of the organization" (Brandsen \& Honingh, 2016, p. 431). This definition emphasizes the co-dependency in citizen-state interactions. While citizens depend on public service in many aspects of everyday life, public service delivery needs the engagement of citizens to improve the service's quality or even to be able to deliver services at all (Alford, 2009; Osborne \& Brown, 2011; Pestoff, 2006). Citizens can both provide the input to and enjoy the benefits of coproduction individually and collectively (Bovaird et al., 2015). In our study, we will focus on philanthropic individual coproduction, where the input is provided individually, whereas the benefits are enjoyed collectively. This constellation is a prime example of a low-cost situation as one individual's decision whether to coproduce or not has no apparent consequences for others (Mensch, 2000). In this situation, individuals should theoretically only rely on their personal preferences. However, no real-life situation is truly without constraints. Mensch (2000) has demonstrated in her analysis of low- and high-cost situations that they are the extreme ends of a spectrum along which individual preferences in decision-making increase in importance with decreasing situational constraints. Applied to our research context, individual preferences translate into motivational antecedents, while situational constraints are framed as facilitating or hindering situational factors.

\section{Motivational antecedents}

Alford (2009) has gained insights from research on volunteering and proposed that, in addition to extrinsic rewards, three different types of motivation are relevant to coproduction: intrinsic, (pro-)social, and normative motivation. As far as extrinsic rewards are concerned, he has argued that citizens do 
not necessarily need them to be motivated to coproduce, because the participation in coproduction is a benefit in itself. A recent study has supported this claim by showing that financial rewards, such as vouchers, only marginally increase the willingness to coproduce language classes for refugees (Voorberg et al., 2018). What is of special interest here is therefore the other types of motivation. First, in the case of intrinsic motivation, the coproduction activity itself might be enjoyable and rewarding: if people are intrinsically motivated, they are more inclined to act pro-environmentally (Steg, 2016). Second, in terms of prosocial motivation, the benefit of participation in coproduction would be to ensure and to enhance the well-being of others. Research has shown that firefighters' prosocial motivation predicts their persistence, reflected in overtime hours (Grant, 2008). Third, in terms of normative motivation, people coproduce because, for them, participation in coproduction is in accordance with their moral values. For example, the attitude toward environmental concerns can have a strong influence on individual recycling decisions in low-cost situations (Diekmann \& Preisendörfer, 2003).

In addition to these motivational dispositions, personal expectations of how one's own actions can lead to a desired outcome, i.e., self-efficacy, might influence whether individuals become engaged (Bandura, 1977). Cross-national studies on correlates of coproduction have found that self-efficacy is a significant explanatory variable for an individual's choice to coproduce public services (Bovaird et al., 2015; Parrado, Van Ryzin, Bovaird, \& Loeffler, 2013). Additionally a study investigating parents' coproduction behavior in educational services found a stronger association of their perceived self-efficacy with coproduction than with their knowledge of how to coproduce (Thomsen, 2017). Again, research on environmental behaviors has also suggested that self-efficacy relates positively to pro-environmental behaviors (Meinhold \& Malkus, 2005; Passafaro \& Livi, 2017).

Based on the literature synthesis, we propose the following hypotheses:

H1a. Intrinsic motivation positively influences citizens' willingness to coproduce.

H1b. Prosocial motivation positively influences citizens' willingness to coproduce.

H1c. Normative motivation positively influences citizens' willingness to coproduce.
H1d. Selfeefficacy positively influences citizens' willingness to coproduce.

\section{Situational factors}

Building on the dimensions of motivation, Verschure and colleagues (2012) have proposed that citizens are also concerned with two facilitating aspects when it comes to engaging in coproduction: the ease with which they can get involved (access to resources) and the reason for their involvement (personal benefit). Easy access to resources can, for example, increase parents' effort in educating their children (Jakobsen, 2013). Reference to the citizens' personal benefit, on the other hand, seems to have less impact on increasing coproduction behavior. For instance, a study has shown that the distribution of brochures about why it is beneficial to practice reading skills with children increased coproduction behavior in parents but only for a very short amount of time (Thomsen \& Jakobsen, 2015). Likewise, offering financial incentives as a personal benefit increased coproduction in language classes for refugees but only marginally (Voorberg, et al., 2018). However, this empirical evidence suggests that both these facilitating situational factors have the potential to increase the individual willingness to coproduce or even actual coproduction behavior under the right circumstances.

We extend this framework by also including a hindering situational factor, performance delay, which is common in public service delivery and an indication of red tape (Bozeman et al., 1992). We consider delays as negative performance information that influences citizens' evaluation of public services (Marvel, 2016) and consequently their willingness to coproduce (Parrado et al., 2013). A field experiment investigating coproduction in educational services found that an increased input to public service delivery from a public organization (school) resulted in an increase in the coproduction behavior of citizens (parents) (Andersen, Nielsen, \& Thomsen, 2015).

Based on previous empirical evidence, we assume the following:

H2a. Access to resources positively influences citizens' willingness to coproduce.

H2b. Personal benefit positively influences citizens' willingness to coproduce.

H2c. Performance delay negatively influences citizens' willingness to coproduce. 


\section{Data and Method}

The strength of existing research often lies in its external validity as many investigations into coproduction initiatives have been conducted in the field. In our study, we have also investigated an actual coproduction initiative of the City of Hamburg that invited citizens to report littering to the city's waste management services. However, in order to increase internal validity, we designed our study as a vignette experiment, giving us the opportunity to isolate the influence of different situational factors. We manipulated the situational factors (in our case, vignettes) and assessed the motivational factors for each person. This design results in a nested data structure (Aguinis \& Bradley, 2014). Although artificial data has several drawbacks, it enables us to investigate how situational factors might subtly shift a situation from a low-cost to a high-cost situation and how this might affect individuals' decision-making.

\section{Participants}

The study was conducted at the beginning of 2018 . Participants were 210 students from two universities in Hamburg, the Universität Hamburg (UHH) and the Helmut-Schmidt Universität (HSU). They were randomly assigned to one of eight sets, which contained three vignettes each. Each set covered between 11 and 13 percent of the total sample of participants. Univariate ANOVA shows that respondents did not differ significantly between the vignettes with regard to age, gender, and study level $(p>$.366). Thus, the sampling error is constant across sets in this clustered random design (Dülmer, 2007). This allows us to analyze willingness to coproduce both between and within persons without providing the full range of vignettes to participants (Beck \& Opp, 2001). Two participants had to be excluded from the analysis for being inattentive, resulting in a final sample of 208 participants. For these individuals, all motivational factors were balanced across the vignettes $(p>$ .130). Sample characteristics of categorical variables can be found in Table 1 .

\section{Procedure}

We asked each participant to read three articles (in a random order) which were based on real articles published in local newspapers at the end of 2017, all beginning with the same description of littering problems in the City of Hamburg. The articles then describe the city's coproduction initiative to tackle the problem of littering in which the three situational factors (i.e., access to resources, personal benefit, and performance delay) vary on two levels. Thus, the vignette experiment is based on a $3 \times 2$ symmetrical orthogonal design, resulting in eight vignettes (Dülmer, 2007). Access to resources is the option to report littering via either (1) an app or (2) a hotline. Personal benefit is the information that (1) an additional garbage fee can be avoided if a certain number of people report littering or that (2) the fee is unavoidable regardless of participation in the initiative. Performance delay is either the information that in 90 percent of the cases, the reported litter will be removed within either (1) one day or (2) five days. Our survey was based on the actual initiative with regard to all dimensions ${ }^{1}$. Appendix A displays the text modules used for the vignettes. After each vignette, participants were asked to rate their willingness to participate in the coproduction initiative.

\section{Measures}

We measured general intrinsic motivation with a 4item scale adapted from Guay and colleagues (2000; $\alpha=.61)$. General prosocial motivation was measured with a 4-item scale adapted from Grant (2008; $\alpha=.83$ ) and general normative motivation was assessed with a 4-item scale adapted from Kim and colleagues $(2013 ; \alpha=.68)$. The general self-efficacy was measured with 3 items from Beierlein and colleagues $(2013 ; \alpha=.76)$. We assessed context-specific intrinsic motivation, prosocial motivation, normative motivation, self-efficacy, the level of cleanliness, and the willingness to coproduce with one item each. Specific motivation was distinguished from general motivational dispositions by explicitly referring to the problem of littering. All items were measured on a 5 -point Likert scale $(1=$ "not at all" to $5=$ "very much"). Appendix B displays the translated wordings.

\section{Estimation Approach}

In our sample, each of the 208 participants gave three ratings on willingness to coproduce, resulting in 624 observations. In order to assess both the effects of motivational antecedents and situational factors in one model, we used the ratings of willingness to coproduce as the unit of analysis, as recommended by Aguinis and Bradley (2014). As these ratings of willingness to coproduce are nested within individuals, we used multilevel modeling to 
Table 1

Sample Characteristics

\begin{tabular}{lcc}
\hline \hline \multicolumn{1}{c}{ Variable } & Value $(\%)$ & \\
\hline Gender & & \\
Female & 92 & $(44 \%)$ \\
Male & 116 & $(56 \%)$ \\
University & & \\
UHH & 117 & $(56 \%)$ \\
HSU & 91 & $(44 \%)$ \\
Study level & 156 & \\
Undergraduate & 52 & $(75 \%)$ \\
Graduate & & $(25 \%)$ \\
Knowledge of app & 8 & \\
Yes & 200 & $(4 \%)$ \\
No & & $(96 \%)$ \\
Knowledge of fee & 28 & $(13 \%)$ \\
Yes & 180 & $(87 \%)$ \\
No & & \\
Residence in Hamburg & 193 & $(93 \%)$ \\
Yes & 15 & $(7 \%)$ \\
No & & \\
\hline
\end{tabular}

Note: $\mathrm{N}=208$ participants.

avoid biased estimates (Finch, Bolin, \& Kelley, 2014).

\section{Results}

Descriptive results show that, on average, respondents possess high general intrinsic, prosocial, and normative motivation, and general self-efficacy. Similarly, context-specific self-efficacy, prosocial, and normative motivation are strong. Only specific intrinsic motivation is lower, meaning that participants enjoy it less being involved in keeping the city clean. The average respondent perceived the city as moderately clean and tended slightly to coproduce. Table 2 displays means, standard deviations, and correlations of all continuous variables.

We conducted multilevel regression analysis to test our hypotheses (see Table 3). In our study, level 1 characteristics concern the unit of observation: ratings of willingness to coproduce. Included in level 1 are the three situational factors and a methodological control variable, specifying the order in which the ratings of willingness to coproduce were given in by participants. Level 2 characteristics are associated with the individual. We included all motivational antecedents and control variables concerning sample characteristics. Additionally, we calculated a multilevel logistic regression to account for ordinally scaled data and the results are robust. For the sake of clarity, we omitted the non-significant control variables (knowledge of the app and fee, study level, and residence) from our results table.

Model 1 shows that on level 1 , access to resources (app preferred over hotline, $\mathrm{b}=0.644, \mathrm{SE}$ $=0.067, \mathrm{p}<0.01)$ and personal benefit (cost avoidance, $\mathrm{b}=0.488, \mathrm{SE}=0.068, \mathrm{p}<0.01$ ) positively influence willingness to coproduce, while performance delay has a negative influence ( 5 day performance delay, $\mathrm{b}=-0.144, \mathrm{SE}=0.069, \mathrm{p}<0.05)$. These results support Hypotheses 2a, 2b, and 2c.

On level 2 Model 1 further shows that specific intrinsic motivation $(\mathrm{b}=0.177, \mathrm{SE}=0.065, \mathrm{p}<$ 0.01 ), specific prosocial motivation $(b=0.286$, SE $=0.105, \mathrm{p}<0.01)$, and specific self-efficacy $(\mathrm{b}=$ $0.196, \mathrm{SE}=0.070, \mathrm{p}<0.01)$ positively influence willingness to coproduce, while all three kinds of 


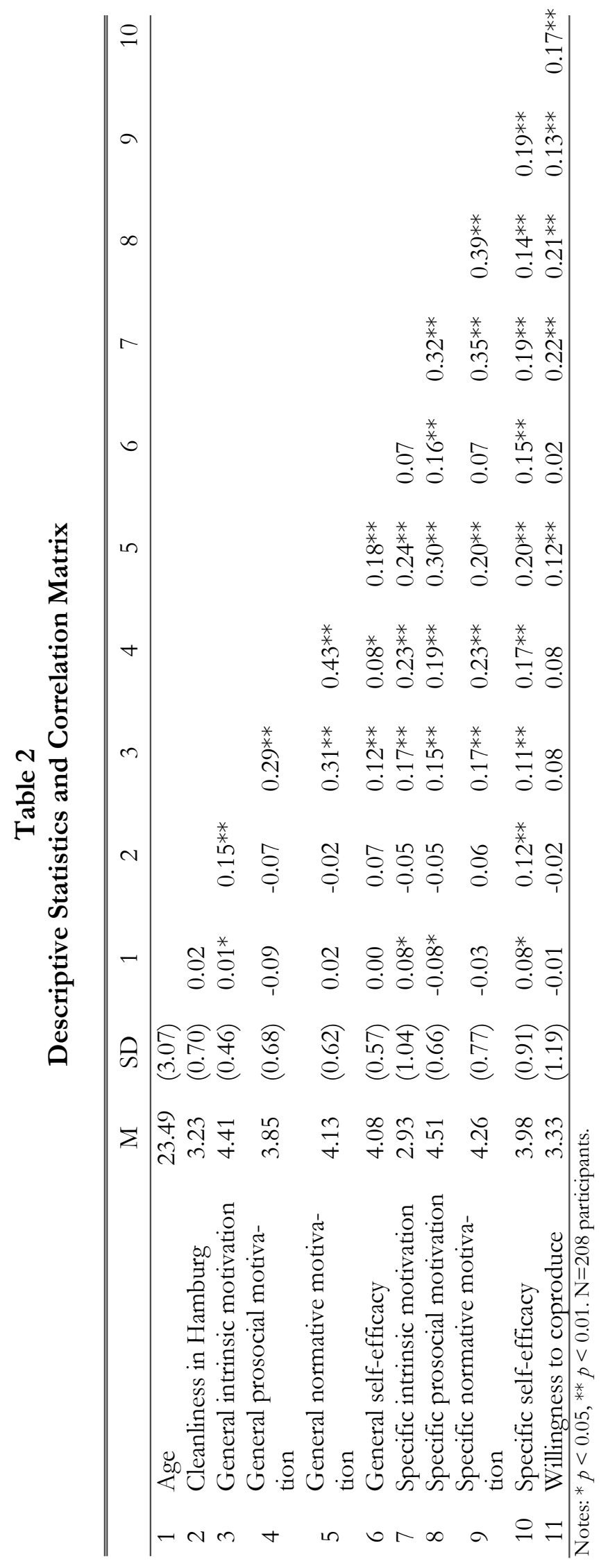


Table 3

Results of Multi-level Regression on Willingness to Coproduce

\begin{tabular}{|c|c|c|}
\hline & \multicolumn{2}{|c|}{ Model I } \\
\hline & Coefficient & SE \\
\hline \multicolumn{3}{|l|}{ Level 1 (decision) } \\
\hline \multicolumn{3}{|l|}{ Situational factors } \\
\hline Access to resources $(0=$ hotline, $1=$ app $)$ & $.644 * *$ & .067 \\
\hline Personal benefit $(0=$ fee, $1=$ no fee $)$ & $.488^{* *}$ & .068 \\
\hline Performance delay ( $0=1$ day, $1=5$ days $)$ & $-.144^{*}$ & .069 \\
\hline \multicolumn{3}{|l|}{ Methodological control variable } \\
\hline Position 2 & $-.244 * *$ & .080 \\
\hline Position 3 & $-.339 * *$ & .080 \\
\hline \multicolumn{3}{|l|}{ Level 2 (person) } \\
\hline \multicolumn{3}{|l|}{ Motivational antecedents } \\
\hline General intrinsic motivation & -.049 & .143 \\
\hline General prosocial motivation & -.024 & .103 \\
\hline General normative motivation & .081 & .114 \\
\hline General self-efficacy & -.146 & .112 \\
\hline Specific intrinsic motivation & $.177 * *$ & .065 \\
\hline Specific prosocial motivation & $.286^{* *}$ & .105 \\
\hline Specific normative motivation & .009 & .089 \\
\hline Specific self-efficacy & $.196^{* *}$ & .070 \\
\hline \multicolumn{3}{|l|}{ Sample control variables } \\
\hline Age & -.003 & .020 \\
\hline Gender $(0=$ female, $1=$ male $)$ & .103 & .150 \\
\hline University $(0=\mathrm{HSU}, 1=\mathrm{UHH})$ & -.193 & .152 \\
\hline Cleanliness in Hamburg & -.008 & .091 \\
\hline Constant & 1.113 & .955 \\
\hline$\sigma^{2}$ & \multicolumn{2}{|c|}{.808} \\
\hline Observations (decisions/persons) & \multicolumn{2}{|c|}{$624 / 208$} \\
\hline
\end{tabular}

general motivations, general self-efficacy, and specific normative motivation are not significantly related to willingness to coproduce. We reject Hypothesis $1 \mathrm{c}$ as neither general nor specific normative motivation significantly influence the willingness to coproduce. Results only partially confirm Hypotheses $1 \mathrm{a}, 1 \mathrm{~b}$, and $1 \mathrm{~d}$ as only context-specific intrinsic motivation, prosocial motivation, and self-efficacy positively influence the willingness to coproduce.

Lastly, level 2 control variables concerning sample characteristics - age, gender, university affiliation, and perceived level of cleanliness in Hamburg - did not influence the willingness to coproduce.
However, on level 1 the position of the vignettes indeed influenced ratings of willingness to coproduce, showing that when vignettes were in second $(b=-0.244, \mathrm{SE}=0.080, \mathrm{p}<0.01)$ or third $(b=-0.339, S E=0.080, p<0.01)$ position, participants reported a lower willingness to coproduce, compared to their rating of the first vignette.

In a post-hoc analysis, we categorized participants into two types of coproducers. Type- 1 individuals $(\mathrm{N}=56)$ were decisive about their willingness to coproduce. Either they always decided to coproduce (rating of 4-5) $(\mathrm{N}=40)$ or always to not coproduce (1-2) $\quad(\mathrm{N}=16)$. Type-2 individuals $(\mathrm{N}=65)$ were flexible about their willingness to coproduce with answers ranging from $1-5$, with at 
Table 4

Results of Multi-level Regression on Willingness to Coproduce for Sub-samples

\begin{tabular}{|c|c|c|c|c|}
\hline & \multicolumn{2}{|c|}{$\begin{array}{c}\text { Model II: } \\
\text { Decisive type } 1\end{array}$} & \multicolumn{2}{|c|}{$\begin{array}{c}\text { Model III: } \\
\text { Flexible type } 2\end{array}$} \\
\hline & Coefficient & SE & Coefficient & SE \\
\hline \multicolumn{5}{|l|}{ Level 1 (decision) } \\
\hline \multicolumn{5}{|l|}{ Situational factors } \\
\hline Access to resources $(0=$ hotline, $1=$ app $)$ & $.249 * *$ & .066 & $1.155^{* *}$ & 144 \\
\hline Personal benefit $(0=$ fee, $1=$ no fee $)$ & $.246^{* *}$ & .066 & $.652^{* *}$ & .150 \\
\hline Performance delay ( $0=1$ day, $1=5$ days $)$ & $-.161 *$ & .067 & $-.329 *$ & .141 \\
\hline \multicolumn{5}{|l|}{ Methodological control variable } \\
\hline Position 2 & .050 & .076 & -.307 & .173 \\
\hline Position 3 & .077 & .076 & $-.721^{* *}$ & .179 \\
\hline \multicolumn{5}{|l|}{ Level 2 (person) } \\
\hline \multicolumn{5}{|l|}{ Motivational antecedents } \\
\hline General intrinsic motivation & -.065 & .426 & -.329 & .196 \\
\hline General prosocial motivation & .241 & .340 & -.063 & .118 \\
\hline General normative motivation & .177 & .330 & -.088 & .147 \\
\hline General self-efficacy & -.170 & .259 & -.185 & .123 \\
\hline Specific intrinsic motivation & $.500^{* *}$ & .181 & .056 & .100 \\
\hline Specific prosocial motivation & .431 & .320 & .001 & .154 \\
\hline Specific normative motivation & -.202 & .259 & .148 & .106 \\
\hline Specific self-efficacy & .089 & .186 & .048 & .087 \\
\hline \multicolumn{5}{|l|}{ Sample control variables } \\
\hline Age & -.034 & .071 & .022 & .022 \\
\hline Gender $(0=$ female, $1=$ male $)$ & .667 & .478 & -.219 & .184 \\
\hline University $(0=\mathrm{HSU}, 1=\mathrm{UHH})$ & -.229 & .471 & -.107 & .193 \\
\hline Cleanliness in Hamburg & -.335 & .253 & .016 & .108 \\
\hline Constant & 1.595 & 3.249 & 1.866 & 1.063 \\
\hline$\sigma^{2}$ & \multicolumn{2}{|c|}{.400} & \multicolumn{2}{|c|}{.980} \\
\hline Observations (decisions/persons) & \multicolumn{2}{|c|}{$168 / 56$} & \multicolumn{2}{|c|}{$195 / 65$} \\
\hline
\end{tabular}

least one decision to coproduce (rating of 4 or 5) and one against coproducing ( 1 or 2). Appendix $\mathrm{C}$ displays the descriptive statistics for the subsamples.

We calculated the multilevel model for both types of coproducers separately, and two distinct patterns emerged. Model 2 in Table 4 shows influences on willingness to coproduce for decisive type- 1 coproducers. In this model all three situational factors, i.e. access to resources $(b=.249, \mathrm{SE}$ $=0.066, \mathrm{p}<0.01)$, personal benefit $(\mathrm{b}=.246, \mathrm{SE}$ $=0.066, \mathrm{p}<0.01)$, and performance delay $(\mathrm{b}=$ $0.161, \mathrm{SE}=0.067, \mathrm{p}<0.05)$ influenced willingness to coproduce. Additionally one motivational antecedent, i.e., specific intrinsic motivation $(b=0.500$,
$\mathrm{SE}=0.181, \mathrm{p}<0.01)$ positively related to the willingness to coproduce. Of these, specific intrinsic motivation had the strongest influence. Model 3 shows that, for flexible type- 2 coproducers, the willingness to coproduce is also influenced by all three situational factors, i.e. access to resources (b $=1.155, \mathrm{SE}=.144, \mathrm{p}<0.01)$, personal benefit $(\mathrm{b}$ $=0.652, \mathrm{SE}=0.150, \mathrm{p}<0.01)$, and performance delay $(\mathrm{b}=-0.329, \mathrm{SE}=0.141, \mathrm{p}<0.05)$. However, motivational antecedents showed no influence. Additionally, flexible type- 2 coproducers rated vignettes in third position $(\mathrm{b}=-0.721, \mathrm{SE}=0.179$, $\mathrm{p}$ $<0.01)$ more negatively than vignettes in first position. 


\section{Concluding Discussion}

The study examined the extent to which motivational antecedents and situational factors influence the willingness of citizens to coproduce a city's environmental services. Based on the results of our vignette experiment, we conclude that context-specific intrinsic motivation, prosocial motivation, and self-efficacy have a positive impact on the willingness to coproduce. Most notably, general intrinsic, prosocial, and normative motivation, and general self-efficacy did not influence the willingness to coproduce. This confirms research in educational psychology, which has pointed out that domainspecific motivations are more important for predicting behaviors than personality traits and general motivational dispositions (Wigfield, 1997). Similarly, Bandura (1997) already concluded that selfefficacy should be studied at a specific level, since skills and expected outcomes vary across domains. Our results support this notion for antecedents of coproduction of environmental issues. This implies that future studies should adapt generic scales to fit the context in order to increase predictive validity.

Furthermore, we found that both access to resources (app over hotline) and personal benefit (cost avoidance) increase the willingness to coproduce, while performance delay slightly decreases the willingness to coproduce. First and foremost, these results stress the importance of information technology as a major driver of citizen coproduction. The purposeful use of social media and customer relationship systems by public administrations has been discussed as a paradigm shift from e-government to "we-government" (Linders, 2012) or "t-government" (" $t$ " stands for transformational; see King \& Cotterill, 2007) which enhances the provision of citizen-centric public services. Since governments and local agencies have only recently begun to experiment with new technologies (Mergel, Rethemeyer, \& Isett, 2016), there seems to be a huge untapped potential for coproduction in the context of environmental issues as well as in other domains. The influence of expected personal benefits on respondents' willingness to coproduce is quite substantial in contrast to previous studies on coproduction (e.g., Voorberg et al., 2018) and environmental behaviors (e.g., Handgraaf, Van Lidth de Jeude, \& Appelt, 2013) that identified only weak effects of monetary incentives. In our model, the effect of personal benefit is larger than the sig- nificant motivational variables. An important difference is that we had framed personal benefit as loss aversion, which is a stronger motivator than a promised gain (Levin et al., 1998). Compared to the other situational factors, an anticipated performance delay of 5 days had a small negative influence on the willingness to coproduce. This supports evidence from cross-sectional surveys showing that the provision of performance information can have a positive (indirect) influence on coproduction (Bovaird et al., 2015; Parrado et al., 2013). Thus, in the modeled low-cost situation, there are constraining factors at play that add to individual preferences (Mensch, 2000).

Post-hoc analysis revealed that these findings do not equally hold for all individuals. As Parrado and colleagues (2013, p. 105) already concluded, "the challenge $[\ldots]$ is to find the relevant incentives for different groups." We found that motivational antecedents and situational factors had different effects on the willingness of the decisive and the flexible types of coproducers. The decisive types had a strong belief about whether to participate in coproduction or not and the three situational factors only slightly influenced the strength of their conviction. The coefficients reveal that context-specific intrinsic motivation had a considerably stronger influence on the coproducers' willingness. In contrast, the flexible type only considered situational characteristics and was not influenced by any motivational antecedent. For them, access to resources had by far the strongest impact on the willingness to coproduce. The two groups differed substantially in the strength of impact of the situational factors, which yields an important implication: shifting the low-cost situation towards higher costs promises an increase in the flexible coproducers' willingness to coproduce, whereas decisive coproducers would remain largely unaffected.

There are, of course, some limitations worth noting. First, our sample is not representative of the city's population. We only asked students in Hamburg who were between 18 and 35 years of age and who all used smartphones. It therefore is not surprising that they found it more convenient to use an app instead of calling a hotline. It is likely that the average population differs with regard to technology use (Deal, Altman, \& Rogelberg, 2010). Although we have no reason to expect other relationships to vary significantly, descriptive results and implications for the design of coproduction initiatives need to be considered with caution. Besides, 
the reliability of the scales for general motivations and self-efficacy performed relatively poorly in our study as compared to the original sources. Although we pretested the survey, and the face-validity of our items was satisfactory, the low reliability might have been caused by the translations of items or because we harmonized answer scales. Another important limitation is that there was a rather strong position effect on flexible participants giving ratings of vignettes. In their first assessment of their willingness to coproduce, participants were on average more positive than in their third assessment. However, order effects are common for respondents with low attitude certainty (Auspurg \& Jäckle, 2017), and due to the random presentation of vignettes within each set, they should not inflate specific relationships (Rossi \& Anderson, 1982). Lastly, we did not assess actual coproduction behavior, just the willingness to coproduce and can therefore only draw limited conclusions from subsequent behaviors. Although the stated willingness did not differ significantly from initiating contact with the public administration in previous studies (Voorberg et al., 2018), future research could try to investigate real coproduction behavior.

To conclude, our study adds to the literature by providing detailed insights into motivational and situational antecedents of coproduction for different types of coproducers. Within the limitations of our analysis, we might also draw some implications for public administrations that want to increase the number of committed citizens. First, they should create awareness of the existing problem and the measures for resolving the issue in order to enhance the context-specific motivation of citizens. The provision of information can be an important policy instrument (Vedung, 1998) and should be in the form of messages conveying fun and social relevance rather than appeals to moral obligations. Second, participants' willingness to coproduce largely depends on an easy access to resources, which is a design feature. This constitutes a great potential for public administrations when trying to increase coproduction behavior of citizens.

\section{Notes}

1. First, the media offered for interacting with the administration are an app (modern option) or a hotline (traditional option). Second, although not exclusively linked to a success in the coproduction initiative, the additional fee has been discussed in the Hamburg Senate. Third, according to the publicly available performance data, the garbage collection services usually collect more than 90 percent of the reported litter within one day.

\section{References}

Aguinis, H., \& Bradley, K. J. (2014). Best practice recommendations for designing and implementing experimental vignette methodology studies. Organizational Research Methods, 17(4), 351-371.

Ahmad, M. S., Bazmi, A. A., Bhutto, A. W., Shahzadi, K., \& Bukhari, N. (2016). Students' responses to improve environmental sustainability through recycling: Quantitatively improving qualitative model. Applied Research in Quality of Life, 11(1), 253270.

Alford, J. (2009). Engaging public sector clients: From servicedelivery to co-production. Hampshire, UK: Palgrave Macmillan.

Andersen, S.C., Jakobsen. M., Seritzlew, S., \& Thomsen, M.K. (2017). Coproduction of public services. In O. James, S.R. Jilke, \& G.G. Van Ryzin (Eds.) Experiments in public management research: Challenges and contributions (pp. 329-344). Cambridge New York, NY Port Melbourne Delhi Singapore: Cambridge University Press.

Andersen, S. C., Nielsen, H. S., \& Thomsen, M. K. (2015). Brugernes reaktion når det offentlige øger serviceniveauet. resultater fra et lodtrækningsforsøg på skoleområdet. Politica, 47(2), 125-143.

Aschhoff, N., \& Vogel, R. (2018). Value conflicts in coproduction: governing public values in multi-actor settings. International Journal of Public Sector Management, 31(7), 775-793.

Auspurg, K., \& Jäckle, A. (2017). First equals most important? Order effects in vignette-based measurement. Sociological Methods and Research, 46(3), 490539.

Bandura, A. (1977). Self-efficacy: Toward a unifying theory of behavioral change. Psychological Review, 84(2), 191-215.

Bandura, A. (1997). Self-efficacy: The exercise of control. New York, NY: Worth Publishers.

Beck, M., \& Opp, K. (2001). Der faktorielle Survey und die Messung von Normen. Zeitschrift für Soziologie, 53, 283-306.

Beierlein, C., Kemper, C., Kovaleva, A., \& Rammstedt, B. (2013). Kurzskala zur Erfassung allgemeiner 
Selbstwirksamkeitserwartungen (ASKU). Methoden, Daten, Analysen (mda), 7(2), 251-278.

Bovaird, T., Van Ryzin, G. G., Loeffler, E., \& Parrado, S. (2015). Activating citizens to participate in collective co-production of public services. Journal of Social Policy, 44(1), 1-23.

Brandsen, T., \& Honingh, M. (2016). Distinguishing different types of coproduction: A conceptual analysis based on the classical definitions. Public Administration Review, 76(3), 427-435.

Brandsen, T., \& Pestoff, V. (2006). Co-production, the third sector and the delivery of public services. An introduction. Public Management Review, 8(4), 493501.

Bozeman, B., Reed, P. N., \& Scott, P. (1992). Red Tape and Task Delays in Public and Private Organizations. Administration \& Society, 24(3), 290-322.

Deal, J. J., Altman, D. G., \& Rogelberg, S. G. (2010). Millennials at work: What we know and what we need to do (if anything). Journal of Business and Psychology, 25(2), 191-199.

Diekmann, A., \& Preisendörfer, P. (2003). Green and Greenback: The behavioral effects of environmental attitudes in low-cost and high-cost situations. Rationality and Society, 15(4), 441-472.

Dülmer, H. (2007). Experimental plans in factorial surveys. Random or quota design? Sociological Methods and Research, 35(3), 382-409.

Finch, W. H., Bolin, J. E., \& Kelley, K. (2014). Multilevel Modeling Using R. Boca Raton: Taylor \& Francis.

Grant, A. M. (2008). Does intrinsic motivation fuel the prosocial fire? Motivational synergy in predicting persistence, performance, and productivity. Journal of Applied Psychology, 93(1), 48-58.

Guay, F., Vallerand, R. J., \& Blanchard, C. (2000). On the assessment of situational intrinsic and extrinsic motivation: The Situational Motivation Scale (SIMS). Motivation and Emotion, 24(3), 175-213.

Handgraaf, M. J. J., Van Lidth de Jeude, M. A., \& Appelt, K. C. (2013). Public praise vs. private pay: Effects of rewards on energy conservation in the workplace. Ecological Economics, 86, 86-92.

Jakobsen, M. (2013). Can government initiatives increase citizen coproduction? Results of a randomized field experiment. Journal of Public Administration Research and Theory, 23(1), 27-54.

Kim, S., Vandenabeele, W., Wright, B. E., Andersen, L. B., Cerase, F. P., Christensen, R. K., ... De Vivo, P. (2013). Investigating the structure and meaning of public service motivation across populations: Developing an international instrument and addressing issues of measurement invariance. Journal of Public Administration Research and Theory, 23(1), 79_ 102.

King, S., \& Cotterill, S. (2007). Transformational government? The role of information technology in delivering citizen-centric local public services. Local Government Studies, 33(3), 333-354.

Latsis, S. J. (1972). Situational determinism in economics. The British Journal for the Philosophy of Science, 23(3), 207-245.

Levin, I., Schneider, S., \& Gaeth, G. (1998). All frames are not created equal: A typology and critical analysis of framing effects. Organizational Behavior and Human Decision Processes, 76(2), 149-188.

Linders, D. (2012). From e-government to we-government: Defining a typology for citizen coproduction in the age of social media. Government Information Quarterly, 29(4), 446-454.

Marvel, J. D. (2016). Unconscious bias in citizens' evaluations of public sector performance. Journal of Public Administration Research and Theory, 26(1), 143158.

Meinhold, J. L., \& Malkus, A. J. (2005). Adolescent environmental behaviors: Can knowledge, attitudes and self-efficacy make a difference? Environment and Behavior, 37(4), 511-532.

Mensch, K. (2000). Niedrigkostensituationen, Hochkostensituationen und andere Situationstypen: ihre Auswirkungen auf die Möglichkeit von Rational-Choice-Erklärungen. Kölner Zeitschrift Für Soziologie Und Sozialpsychologie, 52(2), 246-263.

Mergel, I., Rethemeyer, R. K., \& Isett, K. (2016). Big data in public affairs. Public Administration Review, 76(6), 928-937.

Osborne, S. P., \& Brown, L. (2011). Innovation, public policy and public services delivery in the UK. The word that would be king? Public Administration, 89(4), 1335-1350.

Osborne, S. P., \& Strokosch, K. (2013). It takes two to tango? Understanding the co-production of public services by integrating the services management and public administration perspectives. British Journal of Management, 24(S3), 31-47.

Parrado, S., Van Ryzin, G. G., Bovaird, T., \& Loeffler, E. (2013). Correlates of co-production: Evidence from a five-nation survey of citizens. International Public Management Journal, 16(1), 85-112.

Passafaro, P., \& Livi, S. (2017). Comparing determinants of perceived and actual recycling skills: The role of motivational, behavioral and dispositional factors. Journal of Environmental Education, 48(5), 347-356.

Pestoff, V. (2006). Citizens and co-production of welfare services: Childcare in eight European countries. Public management review, 8(4), 503-519.

Riccucci, N. M., Van Ryzin, G. G., \& Li, H. (2016). Representative bureaucracy and the willingness to coproduce: An experimental study. Public Administration Review, 76(1), 121-130.

Rossi, P. H., \& Anderson, A. B. (1982). The factorial survey approach: An introduction. In P. H. Rossi \& S. 
L. Nock (Eds.), Measuring social judgements: The factorial survey approach (pp. 15-67). Beverly Hills: Sage.

Steg, L. (2016). Values, norms, and intrinsic motivation to act proenvironmentally. Annual Review of Environment and Resources, 41(1), 277-292.

Thomsen, M. K. (2017). Citizen coproduction: The influence of self-efficacy perception and knowledge of how to coproduce. American Review of Public Administration, 47(3), 340-353.

Thomsen, M. K., \& Jakobsen, M. (2015). Influencing citizen coproduction by sending encouragement and advice: A field experiment. International Public Management Journal, 18(2), 286-303.

Vedung, E. (1998). Policy instruments: Typologies and theories. In M.-L. Bemelmans-Videc, R. C. Rist, \& E. Vedung (Eds.), Carrots, sticks and sermons: Policy instruments and their evaluation (5th ed., pp. 21-58). New Brundswick \& London: Transaction Publishers.

Appendix A. Vignettes

\begin{tabular}{|c|c|c|}
\hline & Level & Text modules \\
\hline Introductory text & & $\begin{array}{l}\text { Hamburg. During the last year, there were many calls for making the Han- } \\
\text { seatic City of Hamburg cleaner. The increasing litter problems in the streets } \\
\text { and green spaces of the city has angered its citizens. One example is that } \\
\text { waste and garbage gets caught in the reeds along the banks of the river Al- } \\
\text { ster. The City of Hamburg has now reacted and launched an initiative to re- } \\
\text { duce littering on January } 1 \text { st. This may require an additional garbage fee as } \\
\text { of May } 2018 \text {. }\end{array}$ \\
\hline
\end{tabular}

\begin{tabular}{|c|c|c|}
\hline \multicolumn{3}{|l|}{ Pictures } \\
\hline \multirow[t]{2}{*}{$\begin{array}{l}\text { Access to re- } \\
\text { sources }\end{array}$} & 1 & $\begin{array}{l}\text { You can now also report garbage dumping via a free app. By using the } \\
\text { app, you will be able to upload photos and information about the na- } \\
\text { ture, extent and location of the incident. }\end{array}$ \\
\hline & 2 & $\begin{array}{l}\text { You can now also report garbage dumping via a free hotline. By using the } \\
\text { hotline, you will be able to leave a message on an answering machine } \\
\text { about the nature, extent and location of the incident. }\end{array}$ \\
\hline \multirow[t]{2}{*}{ Personal benefit } & 1 & $\begin{array}{l}\text { The City of Hamburg is considering not charging an additional fee as of } \\
\text { May depending on whether many citizens seize the opportunity to report } \\
\text { garbage dumping directly to the local authorities. }\end{array}$ \\
\hline & 2 & $\begin{array}{l}\text { The City of Hamburg is planning to charge an additional fee as of May } \\
\text { regardless of whether many citizens seize the opportunity to report gar- } \\
\text { bage dumping directly to the local authorities. }\end{array}$ \\
\hline
\end{tabular}




\begin{tabular}{lll}
\hline $\begin{array}{l}\text { Performance de- } \\
\text { lay }\end{array}$ & $\begin{array}{l}\text { After having received the notification, the garbage collection services will } \\
\text { remove the garbage dumping in } 90 \text { percent of the cases within one work- } \\
\text { ing day. }\end{array}$ \\
& $\begin{array}{l}\text { After having received the notification, the garbage collection services will } \\
\text { remove the garbage dumping in } 90 \text { percent of the cases after five working } \\
\text { days. }\end{array}$
\end{tabular}

Appendix B. Scales and Items

\begin{tabular}{|c|c|c|}
\hline Scales & Items & Description \\
\hline $\begin{array}{l}\text { General Intrinsic } \\
\text { Motivation } \\
\text { (Guay et al., 2000) }\end{array}$ & $\begin{array}{l}\text { GIM1 } \\
\text { GIM2 } \\
\text { GIM3 } \\
\text { GIM4 }\end{array}$ & $\begin{array}{l}\text { It is important to me, to do interesting things. } \\
\text { I want to engage in pleasant activities. } \\
\text { My activities should mainly be fun. } \\
\text { I want to feel good in my actions. }\end{array}$ \\
\hline $\begin{array}{l}\text { General Prosocial } \\
\text { Motivation } \\
\text { (Grant, 2008) }\end{array}$ & $\begin{array}{l}\text { GPM1 } \\
\text { GPM2 } \\
\text { GPM3 } \\
\text { GPM4 }\end{array}$ & $\begin{array}{l}\text { I care about benefiting others through my actions. } \\
\text { I want to help others through my actions. } \\
\text { I want to have positive impact on others, } \\
\text { It is important to me to do good for others through my actions. }\end{array}$ \\
\hline $\begin{array}{l}\text { General Norma- } \\
\text { tive Motivation } \\
\text { (Kim et al., 2013) }\end{array}$ & $\begin{array}{l}\text { GNM2 } \\
\text { GNM3 } \\
\text { GNM4 }\end{array}$ & $\begin{array}{l}\text { I admire people who initiate or are involved in activities to aid my } \\
\text { community. } \\
\text { It is important to contribute to activities that tackle social problems. } \\
\text { Meaningful public service is very important to me. } \\
\text { It is important for me to contribute to the common good. }\end{array}$ \\
\hline $\begin{array}{l}\text { General } \\
\text { Self-efficacy } \\
\text { (Beierlein et al., } \\
\text { 2013) }\end{array}$ & $\begin{array}{l}\text { GSE1 } \\
\text { GSE2 } \\
\text { GSE3 }\end{array}$ & $\begin{array}{l}\text { I can trust in my abilities in many difficult situations. } \\
\text { I can master most problems by using my own resources. } \\
\text { I can usually solve even difficult challenges. }\end{array}$ \\
\hline $\begin{array}{l}\text { Specific Intrinsic } \\
\text { Motivation }\end{array}$ & SIM & I enjoy being involved in keeping my environment clean. \\
\hline $\begin{array}{l}\text { Specific Prosocial } \\
\text { Motivation }\end{array}$ & SPM & $\begin{array}{l}\text { It is important to me to keep my environment clean for the sake of } \\
\text { the common good. }\end{array}$ \\
\hline $\begin{array}{l}\text { Specific Norma- } \\
\text { tive Motivation }\end{array}$ & SNM & $\begin{array}{l}\text { Citizens should contribute actively to the cleanliness of the city they } \\
\text { live in. }\end{array}$ \\
\hline $\begin{array}{l}\text { Specific } \\
\text { Self-efficacy }\end{array}$ & SSE & $\begin{array}{l}\text { It makes a difference if individual citizens are involved in keeping } \\
\text { their city clean. }\end{array}$ \\
\hline $\begin{array}{l}\text { Cleanliness in } \\
\text { Hamburg }\end{array}$ & $\mathrm{CHH}$ & How clean is Hamburg as a whole? \\
\hline $\begin{array}{l}\text { Willingness to } \\
\text { coproduce }\end{array}$ & WTC & $\begin{array}{l}\text { How willing are you to report garbage dumping to the local authori- } \\
\text { ties in a situation as described? }\end{array}$ \\
\hline
\end{tabular}

Appendix C. Descriptive Statistics of Sub-Samples

\begin{tabular}{|c|c|c|c|c|}
\hline & \multicolumn{2}{|c|}{ Type 1: decisive $(\mathrm{N}=56)$} & \multicolumn{2}{|c|}{ Type 2: flexible $(\mathrm{N}=65)$} \\
\hline & Value $(\%)$ & Mean (SD) & Value $(\%)$ & Mean (SD) \\
\hline \multicolumn{5}{|l|}{ Gender } \\
\hline Female & $31 \quad(55 \%)$ & & $(35 \%)$ & \\
\hline Male & $25 \quad(45 \%)$ & & $(65 \%)$ & \\
\hline \multicolumn{5}{|l|}{ University } \\
\hline UHH & $22 \quad(39 \%)$ & & $(43 \%)$ & \\
\hline
\end{tabular}




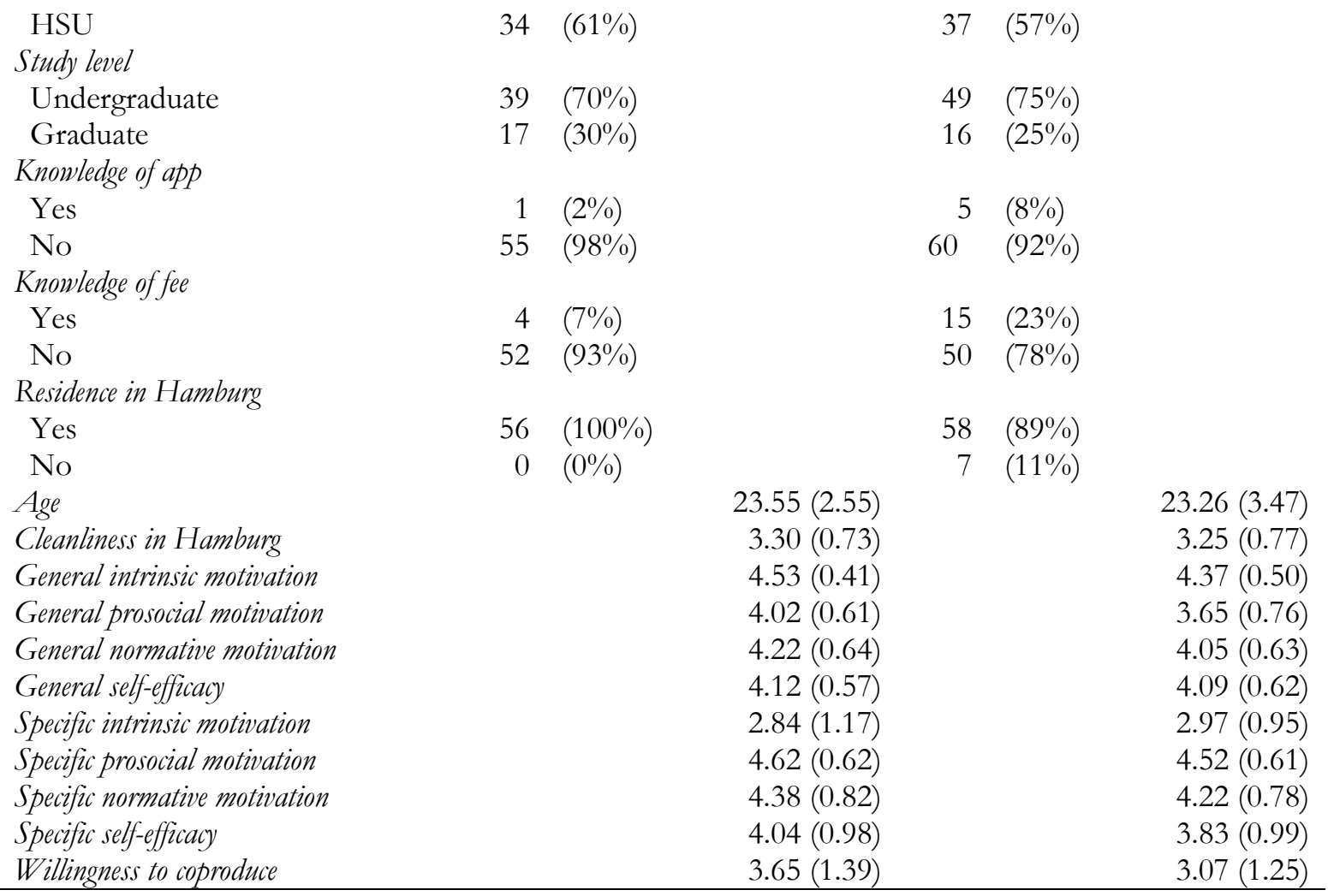

